\title{
A Small Sample of Physical Accessibility in Some Schools in São Paulo - Brazil
}

\author{
Vera Lúcia Messias Fialho Capellini ${ }^{1}$, Elana Simone Schiavo Caramano ${ }^{1}$, Maria Carolina C. Gamba-Yoshida ${ }^{1}$ \& \\ Verônica Rodrigues Mangili ${ }^{1}$ \\ ${ }^{1}$ Education Department, Universidade Estadual Paulista "Julio de Mesquita Filho" - UNESP, Brazil \\ Correspondence: Vera Lúcia Messias Fialho Capellini, Education Department, Universidade Estadual Paulista "Julio \\ de Mesquita Filho" - UNESP, Brazil.
}

Received: June 28, 2016

Accepted: July 15, 2016

Online Published: August 28, 2016

doi:10.5430/irhe.v1n2p197

URL: http://dx.doi.org/10.5430/irhe.v1n2p197

\begin{abstract}
This study deals with the continuous education of teachers in special education, offered by the platform of Sao Paulo Network Program of teacher's formation (REDEFOR), as well as the evaluation of the results of a study conducted by 38 in-course teachers regarding accessibility of 29 schools in the State of São Paulo. The objective, therefore, is to describe the results of the data collected by the in-course teachers about the accessibility conditions in their schools, through the protocol of routes. Evaluating 870 items, 19\% were considered accessible, $18 \%$ were inaccessible, and $68 \%$ were not found adapted elements or accessible. It should be noted, as well, that a high percentage of elements not found, especially the fundamental as ramps (security), signs (communication) and elevators. Considering that the concomitance of accessible and inaccessible elements at the same amount where adapting an environmental requirement in rush in order to obey the legislation.
\end{abstract}

Keywords: inclusive education, school inclusion, accessibility

\section{Introduction}

The history of the inclusion of disabled people in Brazilian society has moved small and slow steps. Since the early society, people with some sort of disability became the target of prejudice, being marginalized, and a lack of treatment or support by the law, which favored its development and a plan for their lives. All you can see were the limitations to the detriment of the skills that could develop. In this sense, "the classical literature and the history of man reflect discriminatory way of thinking because it's easier to pay attention to the impediments and appearances than the potential and capabilities of such people." (Maciel, 2000)

Based on the assertion, the social exclusion begins from the birth, one can see that the measures taken in the relation to the subject are still insufficient. However, Salamanca Declaration (Unesco, 1994) is a way to open the doors to the society for people with disabilities, since, after the family, the school is the medium of interaction for children to develop in the society. The Salamanca Declaration strengthened the social inclusion process that positioned education as a promoter of development and granted a right to all, or propelled the school inclusion. Furthermore, it is provided for children with disabilities to access to a regular school through learning environment and combating discriminatory attitudes. The school must provide all and any differentiated services in order that the disabled person can develop.

The Law No. 9,394/1996, which establishes the Guidelines and Bases for National Education-LDBEN (Brazil, 1996), in force of Brazilian education, proposes some changes in teacher's training courses from its promulgation to require all teachers of basic education in the country, have higher level of education. In 20011, Decree No. 7,611/2011, with constitutional weight, ensures:

an inclusive education system at all levels, without discrimination and on the basis of an equality of an opportunities; learning throughout a life; no exclusion of the General educational system under the claim of a disability; a guarantee of free and compulsory basic education, provided a reasonable accommodation of individual needs; a provision of support required, within the general education system, to facilitate their effective education; an adoption of individualized support and effective measures, in environments that maximize an academic and social development, according to the goal 
of full inclusion; a provision of a special education preferably in regular education network; and the technical and financial support by the Government to private non-profit institutions, specialized and unique performance in the special education. (Decree No. 7,611/2011 in: http://www.planalto.gov.br/ccivil_03/_ato2011-2014/2011/decreto/d7611.htm, accessed on: 10 mar. 2016

So, with the growing demand for the training, from the date of publication of the Declaration of Salamanca and LDBEN, it was necessary to find solutions to train teachers, in particular, those who has only middle-level teacher's training, to serve at the initial years of an elementary school.

The continuous training for teachers is reoccurring theme, whether in the governmental proposals or the public policy. It is known that, in some countries, as well as in Brazil, there is a lack of skilled and specialized professionals, mainly to work with inclusive education in public - that is the basis of formation of the majority of children, adolescents, young people and adults in the country.

However, before the proclamation of the LDBEN, there were also thousands of teachers without the high school education, working in Brazil. According to Gathi and Barreto (2009), in the beginning of 20th century it started the expansion of a basic education in the country, and so, in the years 70's and 80's, it began to grow public schools, and increasing the demand for teachers. According to the authors:

the supply of teachers in the schools goes through several adaptations: an expansion of the normal average level schools, short courses of the formation of teachers, a completion of various origins, special authorizations to exercise of the Magisterium the unlicensed, admission of lay teachers etc (Gathi; BACHA, 2009, p. 11).

With the new LDBEN, it became official by learning a distance (EaD) and, in 2006, the Open University of Brazil (UAB), which aims at the initial training and continuous teachers, making the use of a distance education. In the last decade, the supply and demand for specialization courses at a distance gain a good proportion, and also public universities started to offer new courses.

Among many courses offered, the Department of Education of the State of São Paulo (SEE), in partnership with the State universities, in 2010, offer a teacher training program (REDEFOR). Initially, courses were offered to the disciplines of the curriculum and management courses, and in 2013, it began to offer seven new courses. Among them, the specialization course in Special Education of the Perspective of an Inclusive Education, with 444 hours, and for about 1000 slots. Also the course of specialization in Special Education, with 686 hours, in the areas of Hearing Impairments/Deaf, Visual Impairment, Intellectual Disabilities, Physical Disabilities, Global Development Disorder and High skills or Giftedness.

Each of these six courses made available 100 slots and target audience education Supervisors, Teachers Teaching Core coordinators, Directors, Deputy Directors, Teacher Coordinators, Basic Education Teachers I and II, any categories, with the exception of OFA-category "O" in the Elementary School, the early years and in the disciplines of the Curriculum of Elementary School, Teaching of the Final Years and Education of Young People and Adults, including those who work in the Reading Room and in the Curricular Sporting Activities.

The proposal is the improvement of teachers in the common room Teaching Support Service Specialist (SAPE), as well as sao paulo public school managers, in order to meet, with quality, the audience of special education and to promote the concept of the special education under the inclusive perspective, ensuring equality of the educational law to all. As an example of course offered in the Special Education, in the area of disability, there is the "Accessibility" which is a scope of this work.

The accessibility issue is directly tied to the inclusion that began to widely discuss after the Salamanca Declaration (Unesco, 1994), which encourages and values the common conviviality among the diversity of people. The conviviality between people with disabilities or not, in different environments, mainly in education, could be considered as physical and social spaces. At school, the student must be guaranteed the possibility of safe and independent access (Manzini, 2005). Although the inclusion and the accessibility issues are reoccurring, it is still missing basic aspects that guarantee, in addition to access, the permanence of these students at the school. Several laws were created, but it is still in the theory and the application is doubtful (Mendes, 2006).

The accessibility aims to ensure a participation, with autonomy and independence, of people with disabilities, either temporary or permanent adaptation. The discussion on this topic was initiated with the social inclusion and noted the necessity of modifications in the public places to allow access which is related to the total security or assisted the 
moving spaces and urban facilities, buildings, transport services and methods of communications to the person with a disability or limited mobility.

Manzini (2014) emphasizes the fact that an accessibility is to guarantee adequate conditions of a mobility for all, and especially at the school, and must be the great promoter of a proper accessibility to all students, regardless of whether or not they have a disability or specific need. The planning of adaptation (altering the originality of a space) or fitness (planning the construction of a space) must have an understanding of the needs coming from the different deficiencies in order to carry out the activities of the school environment (Corrêa, P. M, 2007; 2010).

The Ministry of Education, with the goal of supporting public education networks in school inclusion, instituted the Program of Implementation of Multifunctional Resource Classrooms, through Portaria No. 13/24 April of 2007 (Official Gazette, 2007). Such a program serves public schools to have enrollments of students with disabilities. There are two types of rooms: type I and II, by varying the available resources according to the demand of enrolled disabled student. There are plays adapted, braille machine, notebooks, keyboards on hive, spider mobile, headphones, alternative communication, among other features that enable the development and the learning of the student with disabilities (Mantoan, 2010).

The accessibility in the schools can be assessed in several ways, including the evaluation by means of routes is widely used. It is a protocol created by Audi and Manzini (2006) proposes to evaluate all architectural elements, in addition to the paths followed by the student from the school gate to the classroom, including objects that he can find through his route. It was analyzed the widths of doors and gates, handrails, visual and communicative elements, slippery floors or not, rugs and mats, conditions of the dining area, a library, a court, water fountain and bathroom. Finally, all structures which is available at the schools should be in favor of all students, faculties and employees, making ones way or working and proper study environment that adapted for any kind of person with a disability or not.

Based on the study of Tagliari (2006) that aimed to analyze the public schools of Passo Fundo/RS regarding the accessibility. A questionnaire was used to collect data about conditions of an access and the permanence of people with physical disabilities in the schools. As a result, it was found that the majority of educational institutions examined were not adapted to the people with disabilities and only one school was built with the accessibility of the people with disability. It was found that the most schools don't have projects for elimination of architectural and environmental barriers, and it reported diminishing presence of students with physical disabilities. The study suggests that this shows precisely the lack of accessibility at a school for the people with physical disabilities.

This study aimed to describe the results of the data collected by the participants of the REDEFOR teachers, about the accessibility conditions in their schools, regarding the routes.

\section{Methods}

The accessibility data was extracted from 29 studies by 38 teachers who conducted the course of specialization in the Special Education, offered by digital program of REDEFOR, in the area of physical disability, T114EE-DF12 room, discipline accessibility. With a duration of three weeks between March and April 2014 the discipline has been directed to teachers of State schools of São Paulo from some towns and countryside and city of São Paulo, Brazil. Initially, 44 teachers were registered, but through courses it remained 38 course participants, therefore the results of evaluations of accessibility was verified with presented by these teachers at their respective schools.

For the collection of data was employed the instrument for evaluating the physical accessibility of schools, based on the model protocol for evaluation of accessibility in elementary schools, which is developed by Audi and Manzini (2008). This instrument evaluate assesses to school routes, paths or ways that students or employees perform daily at the school, connecting the external and internal environments. These paths must be clear and marked so they can be used autonomously by people without or with disabilities. The external accessible route incorporates, for example, parking lots, demoted sidewalks, ramps, etc., and internal halls, floors, ramps, stairs, elevators, etc.

The Protocol for evaluation of the accessibility in the elementary schools, developed by Audi and Manzini (2008), analyzes routes, paths or ways that students and staff in your school routine, evaluating the connection between the external and internal environments used. The routes that the Protocol allows to evaluate are: route 1 - students entry to set of classrooms; route 2 - set of classroom 1 to room 2 ; route 3 - set of classroom 1 to room 3 ; route 4 classrooms 1 to bathrooms; route 5 - classroom 1 to water fountain; route 6 - classroom 1 to secretary and route 7 classroom 1 to sport court. The twenty-nine schools were evaluated in seven categories of routes: 1) from the front gate to the nearest classroom; 2) from the nearest classroom to the library; 3) from the classroom to the computer room; 4) from the classroom to the bathroom; 5) from the classroom to the water fountain; 6) from the classroom to 
the cafeteria; 7) from the classroom to the sports court. Later it had determined that the presence and adequacy of the following structures present in the Route 1; entrance gate and doors, floor, signal and/or communication, rainwater gullies, rugs or mats, concrete blocks, wide halls, level differences, heights, restrooms and water fountains. Therefore, 10 indicators, determined and listed in: a) accessible; b) inaccessible and c) not found.

Of the 29 schools, each of which is divided into three categories, which, in turn, had the value of ten therefore 870 evaluative items. These three items were computerized in a proportional manner to the number of evaluations, resulting from the ratio between the categories and the total number of evaluations.

\section{Results}

According to the results presented in the studies of teachers in the course, approximately $19 \%$ of twenty-nine schools meets the accessibility standards, $18 \%$ has some inaccessible architectural elements, and $63 \%$ has no element to be considered accessible. A more precise analysis shows that one of the most affordable architectural elements are the gateway, the width of the halls, doors and sewers; while among the inaccessible evidence, drinking fountains, telephones, toilets and ramps, making clear that the adequacy of essential elements such as drinking fountains water; phones - communication; bathrooms - hygiene, and ramps - security have not yet been carried out. Among those considered "non-existent" elements were highlighted the signals (braille, pounds), the ramp and the elevator.

The fact that some schools do not have bathroom adapted and water fountains, is contrary to the principle of universal design, which stresses the importance of size and space for use of any person (Santiago, 2005). The lack of signs for people with visual impairment or other disability types generates insecurity and makes inappropriate environment, besides being a clear mark of exclusion not inclusion (Audi; Manzini, 2006).

Table 1. Architectural elements

\begin{tabular}{lcccccccc}
\hline & \multicolumn{2}{c}{ Accessible } & \multicolumn{2}{c}{ Inaccessible } & \multicolumn{2}{c}{ Not found } & \multicolumn{2}{c}{ Total } \\
\hline & $\mathrm{Fa}$ & $\mathrm{Fr}(\%)$ & $\mathrm{Fa}$ & $\mathrm{Fr}(\%)$ & $\mathrm{Fa}$ & $\mathrm{Fr}(\%)$ & $\mathrm{Fa}$ & $\mathrm{Fr}(\%)$ \\
& & & & & & & & \\
$\begin{array}{l}\text { Architectural } \\
\text { elements }\end{array}$ & 168 & 19 & 157 & 18 & 545 & 63 & 870 & 100 \\
\hline
\end{tabular}

*Fa: factual; Fr: fractional

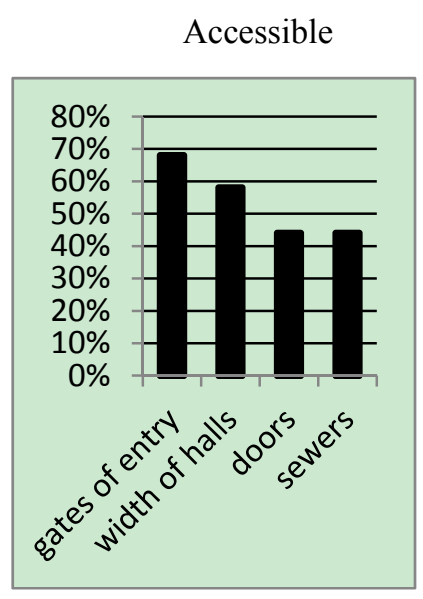

Inaccessible

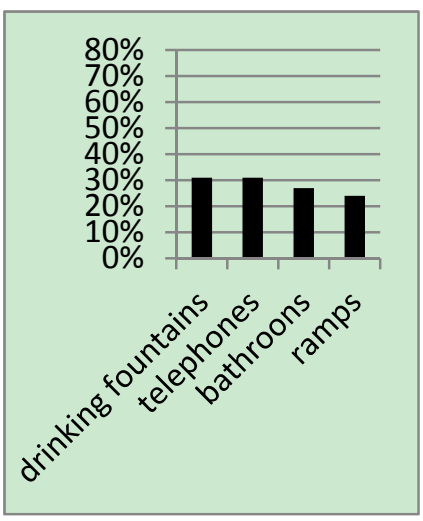

Not Found

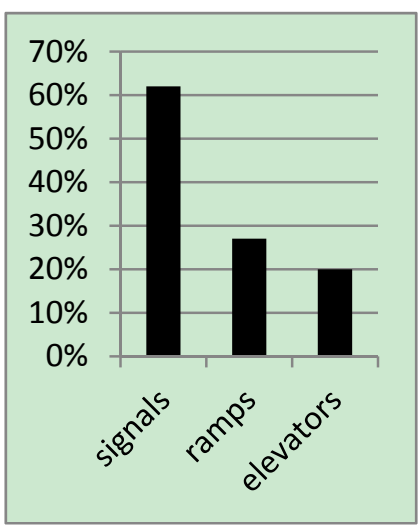

Figure 2. Elements Accessible, inaccessible and not found

A discrepancy between the basic accessible elements and inaccessible and considered not found.

One can observe supremacy in the adaptation of the gates of entry between the accessible elements, followed by the width of halls, doors and sewers. As for the fundamental elements such as drinking fountains, inaccessible (suppliers of water), telephone (communication), bathroom (biological needs) and ramps (security) are almost at the same rate of $30 \%$ to $20 \%$. Among the elements found least, the signal appears with $60 \%$, followed by the ramps and elevators. 


\section{Discussion}

In order to ascertain the implementation of accessibility routes as well as its compliance with the law, this study verified the accessibility of a small sample of Brazilian schools. It's important to demonstrate the current situation of schools and whether they are prepared to receive any people. Since the 90s, Brazil has discussed the issue of accessibility and implemented laws, however, ten years later, what is observed is a superficial accessibility, pointing to the need for greater inspection of the adjustment of routes and Architectural elements, such as the study of Taglari, 2006.

According to the analysis of data collected by teachers in the course, most schools are not prepared physically to receive students with disabilities. Even with all the legislation is in the subject, such as the Declaration of Salamanca, decrees, laws and programs to support school inclusion, the process is not occurring in a satisfactory manner.

The primacy of the school inclusion is welcome all people without exception, considering the ability we all have to learn. For schools to adhere such a precept, political, pedagogical, administrative and structural changes are essential. Based on the knowledge about accessibility and the needs for insertion of architectural or structural changes in the schools (even if it comes up against economic issues), among other necessary adjustments, it can be concluded that the school inclusion process has not yet been realized in practice.

This sample of data collected in studies by teachers in the course of REDEFOR, in twenty-nine schools in São Paulo, suggests that, if expanded the analysis to other States, the reality would not be very different, as noted in the study of Tagliari (2006), which also noted the lag respected to accessibility in more than half of the schools that have been investigated in his research. The fact that some schools do not have bathroom and water fountains adapted, by the contrary to the principle of universal design, which stresses the importance of size and space for use of any person (Santiago, 2005). The lack of signs for people with visual impairment or other disability types generates insecurity and makes inappropriate environment, besides being a clear mark exclusion not inclusion (Audi; Manzini, 2006).

No data were found with respect to the Implementation of Multifunctional Rooms, theoretically, these rooms should be available to all schools that have enrolled students with any kind of impairment, which also puts the process of school inclusion under the doubt.

It is more than necessary for the reflections on the lack of accessibility in the schools in São Paulo, especially in relation to basic elements that must exist in order to provide access and retention of people with disabilities.

The prospects for change are written in the form of the law, but were not translated into political actions, in such a way that there is no direct and effective supervision in the implementation of such changes, which are dragging to come true.

The index of $19 \%$ of schools within the accessibility standard points, however, it's possible a process of school inclusion, enabling the development of the disabled person from the differences and not in uniformity, usually trumpeted, effectively integrating people with disabilities into society.

The heated debates about the inclusion should not be result of fads, but a broad and in-depth debate resulting from a pressing need, for compliance with the laws and guaranteeing the rights of all, especially the underprivileged.

\section{References}

Audi, E.M.M. (2004). Protocolo para a Avaliação da Acessibilidade fisica em escolas de ensino fundamental. Dissertação Mestrado em Educação - Faculdade de Filosofia e Ciências, Universidade Estadual Paulista, Marília, São Paulo, Brasil.

, \& Manzini, E.J. (2006). Protocolo para avaliação da Acessibilidade em escolas do ensino fundamental: um guia para gestores e educadores. Marília: ABPEE.

BRASIL. (1996). Congresso Nacional Lei n0. 9394 de 20 de dez. de 1996. Institui as Diretrizes e Bases da Educação Nacional. Brasília 1996. Retrieved from http:// portal.mec.gov.br/sesu/arquivos/pdf/lei9394.pdf

BRASIL. (1997). Ministério da Justiça. Declaração de Salamanca e Linha de ação sobre necessidades educativas especiais. Brasília: CORDE.

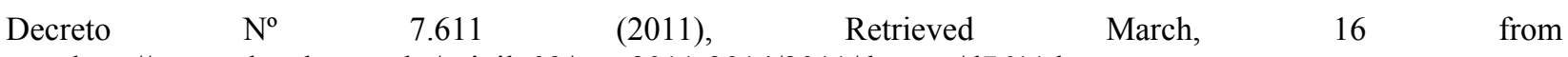
http://www.planalto.gov.br/ccivil_03/_ato2011-2014/2011/decreto/d7611.htm

Educação Inclusiva (Redefor) Retrieved March, 16, 2016, from http://edutec.unesp.br/noticias-edutec-pt-br/2146-redefor-educacao-especial-e-inclusiva-conhecendo-o-curso.ht $\mathrm{ml}$ 
Gathi, B. A., \& Barreto, E. S. S. (2009). Professores do Brasil: Impasses e desafios. Brasília: UNESCO, p. 294.

Jones X. Zeolites, \& synthetic mechanisms. In Proceedings of the First National Conference on Porous Sieves (1999, June, 27-30). Retrieved from http://www.rededosaber.sp.gov.br/portais/Default.aspx?tabid=5028

Lei de Diretrizes e Bases da Educação Nacional. (2009). Retrieved March, 16, 2016, from http://www2.camara.leg.br/documentos-e-pesquisa/publicacoes/edicoes/paginas-individuais-dos-livros/lei-de-di retrizes-e-bases-da-educacao-nacional

Maciel, M. R. C. (2000). Portadores de deficiência: a questão da inclusão social. In Smith Y. Stoneham (Ed.), São Paulo em perspectiva (1996, Vol. 14, No. 2, 16-27, 51-56, 6). Baltimore. Butterworth-Heinemann.

Mantoan, M. T. E., dos Santos, M. C. D., de Figueiredo, R. V., Ropoli, E. A., \& Machado, R. (2010). A educação especial na perspectiva da inclusão escolar: a escola comum inclusiva. Brasília: Ministério da Educação, 1.

Manzini, E.J. (2005). Inclusão e Acessibilidade. Revista da Sobama, 10(1), 31-36.

Mendes, E.G. (2006). A radicaçização do debate sovbre inclusão escolar no Brasil. Revista Brasileira de Educação. 11(33).

Ministério da Justiça. (1997). Declaração de Salamanca e Linha de Ação sobre necessidades Educativas Especiais. Brasília: CORDE.

Paulino, V.C., Correa, P.M., \& Manzini, E.J. (2008). Um estudo sobre a acessibilidade física em nove Escolas Municipais do Ensino Fundamental de uma cidade do interior paulista. Revista de Iniciação Científica da FFC, $8(1), 59-78$.

Tagliari, C., Três, F., \& Oliveira, S. G. D. (2006). Análise da acessibilidade dos portadores de deficiência física nas escolas da rede pública de Passo Fundo e o papel do fisioterapeuta no ambiente escolar. Revista Neurociências, 14(1), 10-14. 